\title{
Evaluation of expression of messenger RNA (RNAm) of the key proteins of the route of the microRNA (miRNA) in RD cells infected with the Mayaro Virus
}

\author{
Avaliação da expressão de RNA mensageiro (RNAm) das proteínas-chave da via do microRNA \\ (miRNA) em células RD infectadas com o vírus Mayaro \\ Evaluación de la expresión de RNA mensajero (RNAm) de las proteínas clave de la ruta del \\ microRNA (miRNA) en células RD infectadas con el Virus Mayaro
}

Received: 01/16/2021 | Reviewed: 01/19/2021 | Accept: 01/24/2021 | Published: 01/31/2021

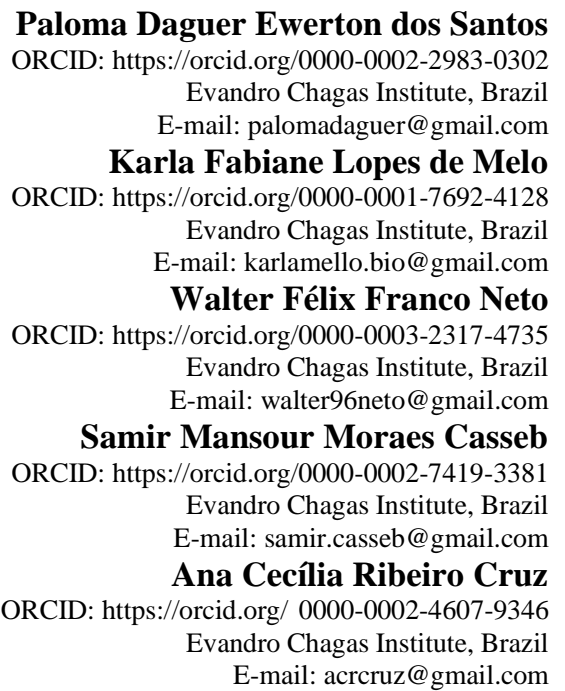

\begin{abstract}
Introduction: The Mayaro virus (MAYV) is an arbovirus belonging to the Togaviridae family of the alphavirus genus, which is transmitted by hematophagous arthropods to vertebrate hosts, whereas non-human primates are considered primary reservoirs. Objective: To evaluate the expression of messenger RNAs (mRNA) of crucial proteins in the microRNA pathway and inflammatory cytokines in human cells during infection by the MAYV. Materials and Methods: Viral samples propagated in RD cell cultures. The RNAs were collected and extracted at predetermined times. The total RNA was then used to detect mRNA by PCR in real time (qRT-PCR). Results: the Mayaro virus RNA was verified in the cells during all the days of infection. The AgR2 mRNA protein dropped sharply by 2 dpi and 3 dpi. Conclusion: The present study demonstrated the reduction of proteins in infection with the Mayaro virus.
\end{abstract}

Keywords: Mayaro virus infection; MicroRNAs; Dicer; Drosha.

\section{Resumo}

Introdução: O vírus Mayaro (MAYV) é um arbovírus pertencente à família Togaviridae do gênero alfavírus, que é transmitido por artrópodes hematófagos a hospedeiros vertebrados, enquanto primatas não humanos são considerados reservatórios primários. Objetivo: Avaliar a expressão de RNAs mensageiros (mRNA) de proteínas cruciais na via de microRNAs e citocinas inflamatórias em células humanas durante a infecção pelo vírus MAYV. Materiais e Métodos: Amostras virais propagadas em culturas de células RD. Os RNAs foram coletados e extraídos em horários predeterminados. O RNA total foi então usado para detectar mRNA por PCR em tempo real (qRT-PCR). Resultados: o RNA do vírus Mayaro foi verificado nas células durante todos os dias de infecção. A proteína AgR2 mRNA caiu drasticamente em 2 dpi e 3 dpi. Conclusão: O presente estudo demonstrou redução de proteínas na infecção pelo vírus Mayaro.

Palavras-chave: Infecção por vírus mayaro; MicroRNAs; Dicer; Drosha.

\section{Resumen}

Introducción: El virus Mayaro (MAYV) es un arbovirus perteneciente a la familia Togaviridae del género alfavirus, que se transmite por artrópodos hematófagos a hospederos vertebrados, mientras que los primates no humanos se consideran reservorios primarios. Objetivo: Evaluar la expresión de RNA mensajeros (RNAm) de proteínas cruciales en la vía del microARN y citocinas inflamatorias en células humanas durante la infección por el virus MAYV. 
Materiales y métodos: Muestras virales propagadas en cultivos de células RD. Los ARN se recogieron y extrajeron en momentos predeterminados. El ARN total se utilizó luego para detectar RNAm por PCR en tiempo real (qRT-PCR). Resultados: se verificó el RNA del virus Mayaro en las células durante todos los días de infección. La proteína de ARNm de AgR 2 se redujo drásticamente en 2 dpi y 3 dpi. Conclusión: El presente estudio demostró la reducción de proteínas en la infección por el virus Mayaro.

Palabras clave: Infección por el virus de mayaro; MicroRNAs; Dicer; Drosha.

\section{Introduction}

The Mayaro Virus (MAYV) belongs to the Togaviridae family, genus Alphavirus. Like other arboviruses, MAYV is transmitted by hematophagous arthropods to wild vertebrate hosts, including non-human primates, rodents, and birds. The latter is considered a secondary host, but essential for spreading the virus (Vasconcelos et al., 2009).

The MAYV infection is mainly characterized by abrupt fever and arthralgia. This worth mentioning that arthralgia is a vital symptom and that it is usually more intense in the small joints of the extremities of the upper and lower limbs, with headache, chills, myalgia, and asthenia, epigastric pain, nausea, lower back pain in addition to diffuse body pain and photophobia. In addition to these symptoms, retro orbital pain and rash have also been reported (Diagne et al., 2020).

The relationship between the immune response and clinical manifestations in patients after infection with the Mayaro virus is not fully established. Many studies have shown that MAYV multiplies in the lymph nodes in the area where the mosquito came into contact with the patient and reached the bloodstream through the lymphatic vessels until it reaches the host's organs and tissues. The virus then multiplies and is released into the bloodstream, triggering viremia.

Viral replication can induce cell death in different ways, such as apoptosis, necrosis, or autophagy. In the case of arthritogenic alphavirus, cell death is commonly associated with the activation of apoptotic machinery and appears to be related to the inflammatory response.

The participation of miRNAs in various functional processes of cells, such as proliferation, survival, and apoptosis, began to be established and their participation in diseases' pathophysiology. So far, 11 viruses have been discovered that can encode their miRNA, such as the Epstein- Barr virus, human cytomegalovirus, the human immunodeficiency virus type 1 (HIV-1), among others (Pfeffer et al., 2005).

As miRNAs are closely related to viral infection, advances in understanding this complex interaction can become markers for diagnosis, prognosis, or even future therapy.

The production of miRNAs is a complex and coordinated process, in which different groups of enzymes and nuclear and cytoplasmic proteins operate. The process starts at the nucleus by transcribing a precursor, RNA polymerase II, called primiRNA, formed and processed by the Drosha-DGCR8 complex, which cleaves the pri-miRNA and produces pre-miRNA. That is a double-stranded miRNA in the form of a clamp, with about 70 nucleotides and protrusion of two nucleotides in 3 'region, making the pre-miRNA recognized Exportina-5 and transported to the cytoplasm via GTP (Sonkoly et al., 2009).

When in the cytoplasm, this pre-miRNA is processed by the TRBP- Dicer duplex, losing the loop and becoming a mature double-stranded miRNA with about 22 nucleotides. Then, TRBP changes its conformation and, still linked to Dicer, recruits the protein Argonauta-2 to form the trimeric ribonucleoprotein complex called RISC. Thus, one of the tapes matures miRNA is selected to remain attached to the complex, while the other is degraded (Chendrimada et al., 2005).

Thus, miRNAs, when loaded on Argonaute proteins, regulate gene expression, antagonize viral infection and transposable elements and preserve integrity, since proteins silencing genes by cutting mRNA targets through their endonuclease activity or the recruitment of gene silencing effectors (Denli et al., 2004).

The previous studies from miRNAs and arboviruses, such as dengue and yellow fever, the results demonstrated that is, in fact, a relationship between the infection of the arboviruses above and the pathway of miRNAs such as that of Holanda et al. (2017) and Casseb et al. (2016). 
Thus, this work has great relevance when verifying the relationship of miRNAs and Argonaute proteins with the Mayaro virus, since data like this have not yet been described for this virus, giving this work a great character of originality.

This work aims to evaluate the mRNA expression of the Argonaute proteins of the canonical path of s microRNA s in Human cells during the infection of the MAYV virus.

\section{Methodology}

\section{Viral Strains and Cell Culture}

The viral samples were obtained from collecting viral isolations of the Section of Arbovirology and Hemorrhagic Fevers of the Evandro Chagas Institute. The samples used correspond to strains of MAYV isolated from the blood and serum of patients from an outbreak of MAYV in Santa Bárbara, PA, with identification Be H774173.

The viral samples were propagated in cell cultures by inoculating the viral suspensions in $175 \mathrm{~cm} 2$ bottles containing confluent monolayers of RD cells (Human striated muscle sarcoma cells) maintained in Dulbecco's modified Eagle medium containing sodium pyruvate (110 mg/L) (DMEM - Invitrogen, USA), and $2.2 \mathrm{~g} / \mathrm{L}$ of sodium bicarbonate, $20 \mathrm{mM}$ HEPES, 4 mM L-glutamine (Sigma, USA) will be added. The growth medium contains $10 \%$ SBF and the maintenance medium, $2 \%$.

\section{Rna Obtaining and Analysis}

The total RNA of the cells was extracted with the commercial kit Trizol plus (Ambion, Carlsbad, USA) following the protocol described by the manufacturer. The determination of the material's concentration and purity was carried out with the aid of the Qubit device (Invitrogen Life Technologies, Carlsbad, USA) and using a commercial kit Qubit RNA Assay (Invitrogen Life Technologies, Carlsbad, USA) according to the manufacturer's description.

The RNA Total cellular, both of infected samples as controls (MOCK), were used for the relative quantification of the expression of mRNA targets.

The cDNAs were diluted 1:10 in $\mathrm{H} 2 \mathrm{O}$ and $1 \mu \mathrm{L}$ of each sample will be submitted to the qRT -PCR using the Power SYBR Green PCR Master Mix (Applied Biosystem, USA). The samples were subjected to the first stage of $95^{\circ} \mathrm{C}$ for 10 minutes (min.) Moreover, 45 amplification cycles consisting of DNA denaturation for $30 \mathrm{~s}$ at $95^{\circ} \mathrm{C}$, annealing of the primers for $30 \mathrm{~s}$ at $55^{\circ} \mathrm{C}$ and a dissociation stage. The thermal cycler was used to monitor the SYBR Green signal at the end of each extension period for 45 cycles.

The quantification of the expression of miRNAs mature scored based on the Cts obtained using the equation Math 2$\Delta \Delta \mathrm{Ct}$ (Schmittgen, 2001). In this method, we compare endogenous genes with our target genes and our negative control with samples infected with MAYV. The primers used for expression mRNA are described in Table 1, our endogenous control being the RPL38 target. 
Table 1: Oligonucleotides that were used to analyze the expression of proteins in the microRNA pathway.

\begin{tabular}{|c|c|c|}
\hline Name & Sequence 5' - 3' & Size \\
\hline Drosha - Foward & CAAAGGCAAGACGCACAG & (18 bases) \\
\hline Drosha-Reverse & CATAGGACGACAGGGCTTG & (19 bases) \\
\hline Dicer - Foward & TGGAGACAGTCTGGCAGGTGTA & (22 bases) \\
\hline Dicer $-\mathrm{R}$ & TCCCGTCGTAAGTTCTCTCAGC & (22 bases) \\
\hline Argonauts 1- Foward & GACCTCCGCACGGGTATATG & (23 bases) \\
\hline Argonauts 1- Reverse & GGTTTCCCCACAGTGCCAAT & (20 bases) \\
\hline Argonauts 2- Foward & TGGTTTGGCTTCCATCAGTCC & (21 bases) \\
\hline Argonauts 2- Reverse & CCTTGTAAAACGCTGTTGCTGAC & (23 bases) \\
\hline Argonauts 3- Foward & ACCTGTGGGGCGTTCATTT & (19 bases) \\
\hline Argonauts 3- Reverse & GCCGAACAGACTGATGGAAT & (20 bases) \\
\hline Argonauts 4- Foward & СТСАССТСАААСССТТТССААТСТT & (24 bases) \\
\hline Argonauts 4- Reverse & AGGCTGCTGGAACACCGAG & (19 bases) \\
\hline DGCR8- Foward & GCAAGATGCACCCACAAAGA & (19 bases) \\
\hline DGCR8- Reverse & TTGAGGACACGCTGCATGTAC & (20 bases) \\
\hline IFN-ALPHA- Foward & CTTGATGCTCCTGGCACAGA & (18 bases) \\
\hline IFN-ALPHA- Reverse & TCATGGAGGACAGGGATGGT & (19 bases) \\
\hline IFN-BETA- Foward & TAGCACTGGCTGGAATGAGA & (19 bases) \\
\hline IFN-BETA- Reverse & TCCTTGGCCTTCAGGTAATG & (18 bases) \\
\hline RPL38- Foward & TCACTGACAAAGAGAAGGCAGAGA & (20 bases) \\
\hline RPL38- Reverse & TCAGTGTGTCTGGTTCATTTCAGTT & (20 bases) \\
\hline
\end{tabular}

Source: Authors.

\section{Quantitation of Viral Load using Real Time Qrt-Pcr}

For the quantification of the viral load, we use the following initiators (Table 2) together with the absolute quantitation using the standard curve method and plasmid as cloning vector pGEM Easy (Promega, USA).

Table 2: Oligonucleotides that were used to quantify viral load by Real Time RT-qPCR.

\begin{tabular}{|c|c|c|}
\hline Name & Sequence 5' $-3^{\prime}$ & \multirow{2}{*}{ Amplicon } \\
\cline { 1 - 2 } MAYqPCR - 1- Foward & CGCGTGCCATGCGGGGA & \multirow{2}{*}{$200 \mathrm{pb}$} \\
\cline { 1 - 2 } MAYqPCR - 1- Reverse & GGCGGTGATCGGCAGCGT & \\
\hline MAYqPCR- Probe & [FAM] CGCCACGGTACGACCACGCA [BHQ1] & \\
\hline
\end{tabular}

Source: Authors.

\section{Statistical Analysis}

The statistical analysis of the data was carried out using the software pyQPCR (Hellemans J et al, 2007) and the R Project with the qPCR.Ct pack (PAN, 2012). The samples were compared and analyzed using ANOVA, and P-values less than 0.05 were considered statistically significant. 


\section{Results}

It was verified by quantifying RNA of the Mayaro virus in the cells during all the days of infection, showing a higher index of viral production on the 4th day after infection (4dpi), as shown in the Figure 1.

Figure 1: Chart of Viral Load of days post-infection x copies of the genome

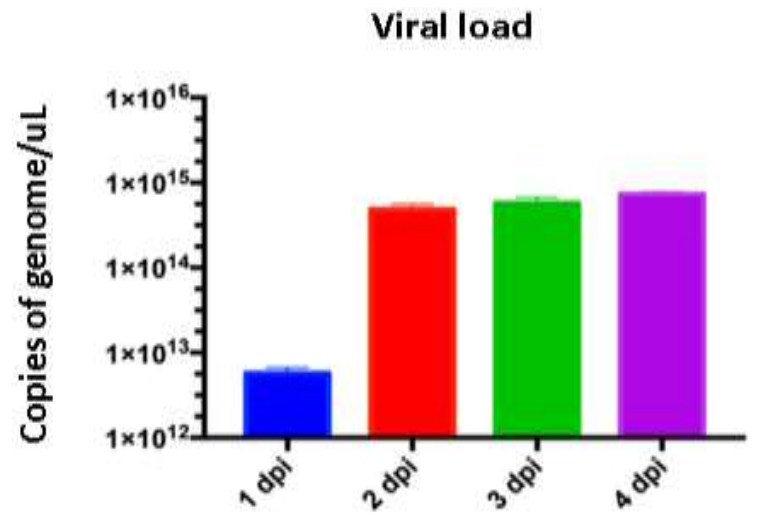

Days post-infection

Source: Authors.

In the figure above, it is possible to observe that the viral load or copies of the virus genome increased abruptly from the first to the second day post-infection, while in the following two days, despite having an increase, it was very small.

When analyzing the expression profile of the mRNA s of the Argonauts proteins, it was found that, despite the increase in viral load, there was a decrease in the expression of proteins from 2dpi with different profiles in Figure 2. 
Figure 2: Graphs of mRNA expression of Argonaut proteins 1, 2, 3, and 4 to days after infection and mRNA.
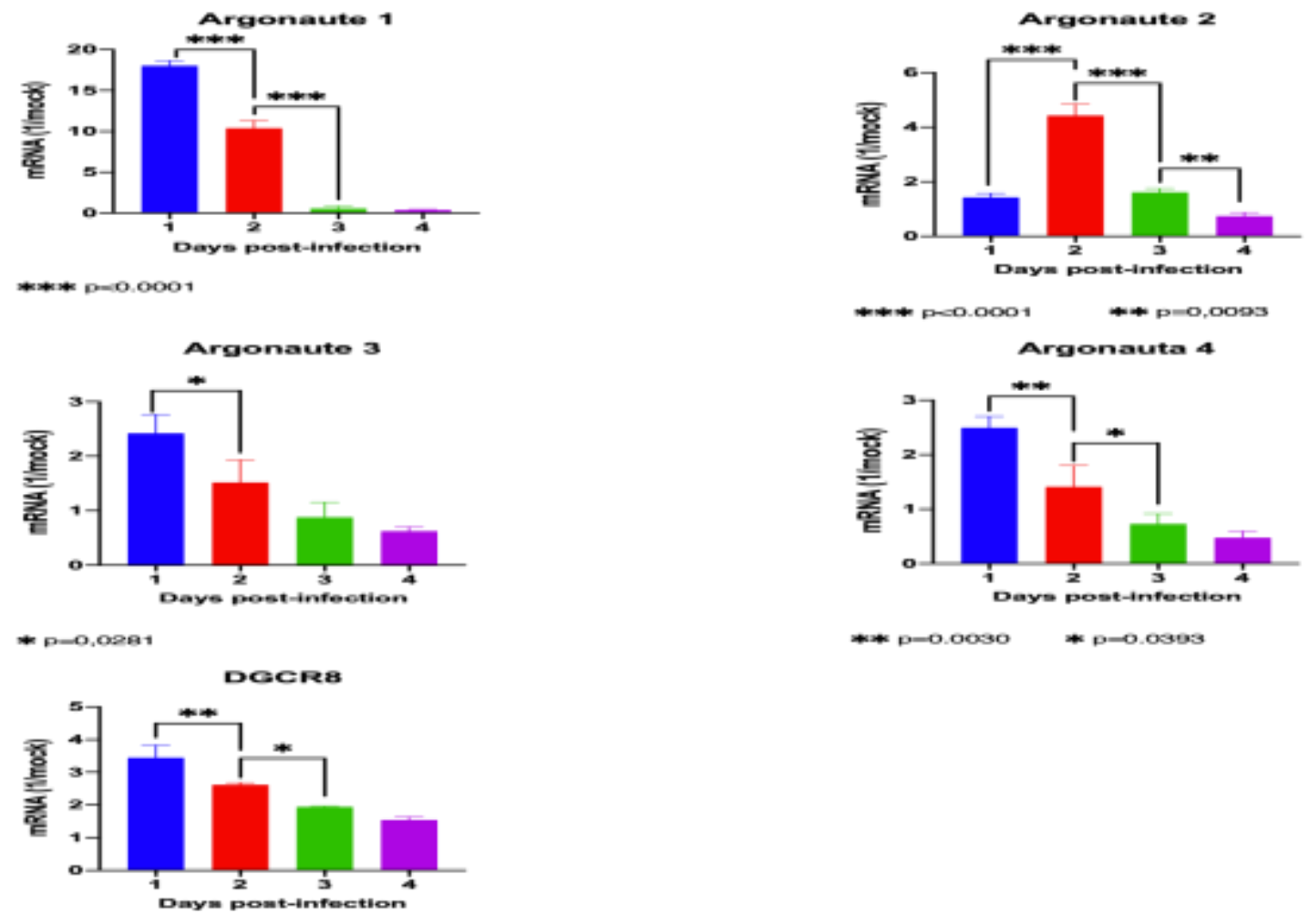

In the figure: (a) Profile of Argonaut 1; (b) Profile of Argonaut 2 ; (c) Profile of Argonaut 3 and ( d ) Profile of Argonaut 4 and (e) DGCR8 Source: Authors.

In Figure 2 (a), the profiled mRNA from Argonaut 1 decreases slightly in 2dpi and drastically at 3:04 dpi. In contrast, the profile of mRNA from Argonaut 2 drastically decreases on the second day after infection and begins to increase in the third and fourth day in figure 2 (b) Regarding the mRNA to Argonaute 3, the profile decreases every day, according to Figure 2 (c), similar to the mRNA profile of Argonaute 4 and DGCR8 in figure 2 (d, e).

Regarding the immunological profile, as shown in Figure 3, the amount of IFN-Alpha decreased over the days, starting at 2dpi, while IFN-Beta first increased at 2dpi and 3dpi and 4dpi started to decrease. 
Figure 3: Graphs of expression of Interferons Alpha and Beta concerning days after infection and mRNA.

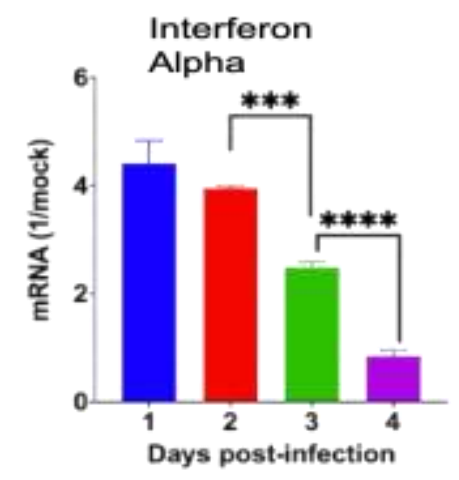

*** $p=0,0002$

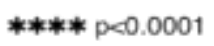

***** p<0.0001
Interferon Beta

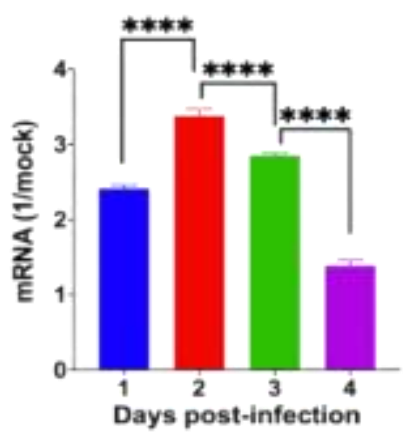

***** p-0.0001

In the figure: (a) IFN-Alpha profile and (b) IFN-Beta profile.

Source: Authors.

The decrease in alpha interferon after the second day was significant with $p=0.0002$ and on the third day for the fourth day it was even more significant with $p=0.0003$. In relation to interferon beta, the increase from the first to the second day and the decreases from the second to the third day and from the third to the fourth day were significant with $\mathrm{p}=0.0001$.

The present work carried out a statistical comparison process with a direct relationship between viral load and Argonaute protein mRNAs, finding significance with Argonaut 2 mRNA, as shown in Figure 4.

Figure 4: Graphs of the direct relationship between viral load and Argonaute2 mRNA.

Mayaro vs Argonaute 2

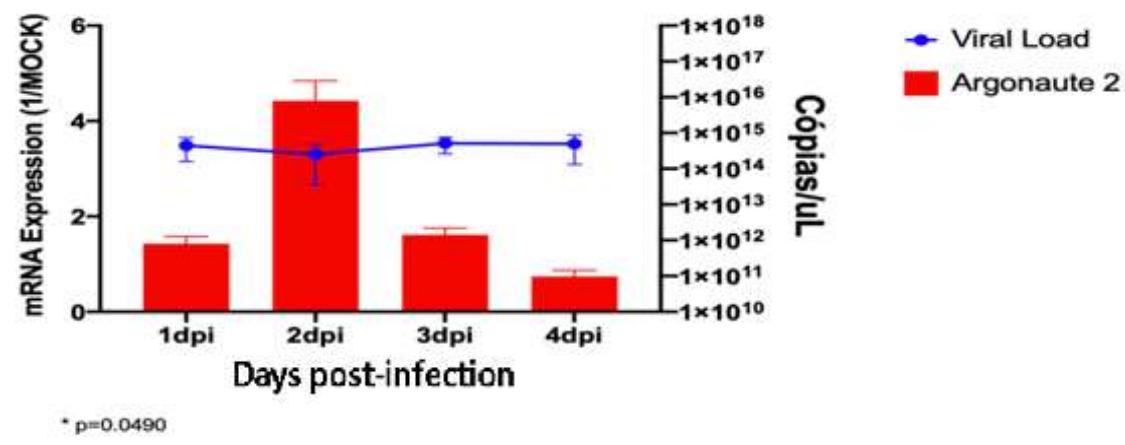

Source: Authors.

It is important to note that although the viral load increases from the second day onwards after infection, the Argonaute 2 protein increased only from the first to the second day, decreasing from the third day onwards.

\section{Discussion}

The present study demonstrated a decrease in the expression of mRNAs of Argonautes 1, 2, 3, and 4 and DGCR8 proteins after infection of RD cells by the Mayaro virus when compared to control cells.

Such an expression had already described in Holanda et al. (2017), where the author observes this pattern for the Yellow Fever virus (Flavivirus), and it describes that the Argonauts described above modulated the expression of mRNAs 
from proteins in the canonical pathway of miRNA, except for Ago 03.

In a study with the Zika virus, Ferreira et al. (2018) also identified that mRNA expression levels of DGCR8, Ago1, and Ago3 differed during the 4 days of infection (dpi), with the highest levels of expression observed at 3 and 4 dpi for DGCR8, 1 dpi for Ago1 and 3 dpi for Ago3.

Such findings suggest that viral infection plays an essential role in regulating mRNAs in proteins in the miRNA pathway, contributing to viral replication and modulating infected cells' immune response.

It is essential to highlight that Argonautes proteins are part of the RISC complex, which has a function well described as gene silencing, and their decrease during viral infection has become an essential target in studies both in terms of infection and also of the immune response, verifying the modulation of viral pathogenesis (Perron et al., 2009).

Besides, it has been described that Ago2 protein plays a role in controlling lymphoid and erythroid cells, being essential for the miRNA silencing pathway. Studies have also reported that only Ago2 has mRNA cleavage activity since it interacts directly with the GW182 protein to form an entire complex for gene silencing (Smibert et al., 2013).

Protein expression can also be used as a biomarker during viral infection for treatments or prognostic measures. It has already been demonstrated in studies with HVB that viral infection deregulation of miRNA expression can induce the reduction of interferon and, consequently, the immune response to HBV (Wang et al, 2012 and Zheng et al, 2016).

Such results can be corroborated because the alpha and beta interferons decrease over the days, demonstrating that the decrease in the Argonauts protein mRNAs may have induced the decrease in the cells' immune profile after infection.

Flaviviruses have been shown to induce downregulation in cellular miRNA expression by targeting miRNA processing enzymes. The modulation of the host's cellular miRNAs has been shown to contribute to specific cell tropism in response to infection and the development of encephalitic alphavirus disease (Sharma et al, 2015)

In a study of mRNA expression of Dicer-1, Drosha, AGO1, and AGO2 downregulated in neurons infected with ZIKV, compared to neurons infected with a simulation at 24 and $48 \mathrm{~h}$, where mRNA expression of DGCR8 increased slightly in $24 \mathrm{~h}$, followed by a decrease in expression in $48 \mathrm{~h}$ such as the present study (Azouz et al, 2019).

Moreover, after analysis using processes of comparison between the direct viral load relationship in the days after infection with Argonaute protein mRNAs, the relationship with Argonaut 2 mRNA, which is a virus-related protein, was statistically significant, as already described by Casseb and collaborators corroborating the present study.

\section{Conclusion}

Thus, the present study demonstrating the decrease of proteins in the Mayaro virus infection corroborates the studies on the modulation of the immune response during the infection. It is necessary that more studies be done to search for biomarkers of therapeutic targets using miRNAs and their essential proteins.

\section{Acknowledgments}

Research supported by CNPq/CAPES and IEC/SVS from the Brazilian government.

\section{References}

Azouz, F., Arora, K., Krause, K., Nerurkar, V. R., \& Kumar, M. (2019) Integrated microrna and mrna Profiling in Zika Virus-Infected Neurons. Viruses 11 (162). $10.3390 / \mathrm{v} 11020162$

Casseb, S. M. M., Simith, D. B., Melo, K. F. L., Mendonça, M. H., Santos, A. C. M., Carvalho, V. L., Cruz, A. C. R. \& Vasconcelos, P. F. C. (2016). Drosha, DGCR8, and Dicer mrnas are down-regulated in human cells infected with dengue virus 4, and play a role in viral pathogenesis. Genetics and Molecular Research 15 (2): gmr.15027891 
Chendrimada, T. P., Gregory, R. I., Kumaraswamy, E., Norman, J.; Cooch, N., Nishikura, K. \& Shiekhattar, R. (2005). TRBP recruits the Dicer complex to Ago2 for microrna processing and gene silencing. Nature 4;436(7051):740-4. 10.1038/nature03868.

Denli, A. M., Tops, B. B. J., Plasterk, R. H. A., Ketting, R. F. \& Hannon, G. J. (2004) Processing of primary micrornas by the Microprocessor complex. Nature11;432(7014):231-5. 10.1038/nature03049.

Dagne, C. T, Bengue, M., Choumet, V., Hamel, R., Pompon, J., \& Missé, D. (2020). Mayaro Virus Pathogenesis and Transmission Mechanisms. Pathogens 8;9(9):738. 10.3390/pathogens9090738.

Ferreira, R. N., Holanda, G. M., Silva, E. V. P., Casseb, S. M. M., Melo, K. F. L., Carvalho, C. A. M., Lima, J. A., Vasconcelos, P. F. C., \& Cruz, A. C. R. (2018) Zika Virus Alters the Expression Profile of microrna-Related Genes in Liver, Lung and Kidney Cell Lineages. Viral Immunology Volume 00, Number 00 .

Holanda, G. M., Casseb, S. M. M., Mello, K. F. L., Vasconcelos, P. F. C., \& Cruz, A. C. R. (2017) Yellow Fever Virus Modulates the Expression of Key Proteins Related to the microrna Pathway in the Human Hepatocarcinoma Cell Line hepg2. Viral Immunol. 30(5):336-341. 10.1089/vim.2016.0149.

Perron, M. P. \& Provost, P. (2009) Protein components of the microrna pathway and human diseases. Methods in Molecular Biology 487: 369-385.

Pfeffer, S., Sewer, A., Lagos-Quintana, M., Sheridan, R., Sander, C., Grasser, F. A., Van Dyk, L. F., Ho, C. K., Shuman, S., \& Chien, M. (2005). Identification of micrornas of the herpesvirus family. Nat. Methods 2, 269-276.

Sharma, A., Balakathiresan, N. S. \& Maheshwari, R. K. (2015). Chikungunya Virus Infection Alters Expression of micrornas Involved in Cellular Proliferation, Immune Response and Apoptosis. Intervirology 58:332-341

Smibert, P., Yang, J. S., Azzam, G., Liu, J. L. \& Lai, E. C. (2013). Homeostatic control of Argonaute stability by microrna availability. Nat Struct Mol Biol. 20(7):789-95. 10.1038/nsmb.2606.

Sonkoly, E. \& Pivarcsi, A. (2019). Micrornas in inflammation. Int Rev Immunol. 28(6):535-61. 10.3109/08830180903208303

Vasconcelos, P. F. C., Travassos-da-Rosa, A. P. A., Pinheiro, F. P., \& Travasos-da-Rosa, J. F. S. (2009). Arboviroses. In: Veronesi-Focaccia, R; Diament, D; Ferreira, MS \& Siciliano, RF. Veronesi-Focaccia: Tratado de Infectologia, Editora Atheneu. (4º edição), São Paulo, 1, 339-351. 2009.

Wang, S., Qiu, L., \& Yan, X. (2012) Loss of microrna 122 expression in patients with hepatitis B enhances hepatitis B virus replication through cyclin G1modulated P53 activity. Hepatology 55:730-741.

Zheng, Q., Hou, J., \& Zhou, Y.(2016) Type I IFN_-inducible downregulation of microrna-27a feedback inhibits antiviral innate response by upregulating Siglec1/TRIM27. J Immunol 196:1317-1326. 